\title{
DETRITAL SHOCKED ZIRCON PROVIDES FIRST RADIOMETRIC AGE CONSTRAINT OF <1472 MA FOR THE SANTA FE IMPACT STRUCTURE, NEW MEXICO, USA
}

MONTALVO, Pedro E. ${ }^{1}$, CAVOSIE, Aaron J. ${ }^{2}$, KIRKLAND, Christopher L. ${ }^{2}$, EVANS, Noreen J. ${ }^{2}$, MCDONALD, Bradley J.2, TALAVERA, Cristina ${ }^{3}$, ERICKSON, Timmons M. ${ }^{4}$ and LUGO CENTENO, Cristina ${ }^{5}$, (1)Department of Geology, University of Puerto Rico - Mayaguez, P.O. Box 9000, Mayaguez, PR 00681, (2)Space Science and Technology Centre, School of Earth and Planetary Science, Curtin University, Perth, 6102, Australia, (3)School of Geosciences, University of Edinburgh, The King's Building, James Hutton Road, EH93FE, Edinburgh, EH93FE, United Kingdom, (4)Jacobs - JETS, ARES division, NASA Johnson Space Center, 2101 NASA Parkway, Houston, TX 77058, (5)Earth Sciences, Syracuse University, 204 Heroy Geology Laboratory, Syracuse, NY 13244

Impact structures are prone to erosion, burial and tectonic deformation. The Santa Fe impact structure in New Mexico contains shatter cones and shocked quartz, but is highly tectonized and eroded; estimates of the impact age (1200-300 Ma) and size (6-13 km) are poorly constrained [1]. Here we report the first occurrence of shock-twinned zircon identified both in modern sediments and bedrock at the Santa Fe impact structure. Zircon $\{112\}$ twin lamellae are considered diagnostic evidence of shock deformation and have been identified at several impact structures including Vredefort [2-4], Sudbury [5], Ries [6], Rock Elm [7], and in lunar impact breccia [8].

A total of 6619 grains from fifteen sediment samples and two rock samples were surveyed; seven shocked grains were identified $(7 / 6619=0.1 \%)$. One shocked zircon was identified in a biotite schist shatter cone. Five of seven shocked zircon grains were EBSD mapped; three were analyzed with multiple SIMS spots. EBSD mapping revealed $\{112\}$ deformation twin lamellae in each of the five zircon grains. U-Pb geochronology for three of the shocked zircon grains yield crystallization ages from $1715 \pm 22$ to $1472 \pm 35 \mathrm{Ma}$. LA-ICPMS U-Th-Pb analysis of detrital zircon grains from five samples yielded Paleoproterozoic (1800-1600 Ma) and Mesoproterozoic (1500$1300 \mathrm{Ma})$ ages.

We reveal the first confirmed shocked zircon at the Santa Fe structure. Zircon is the third shocked mineral identified at this site, in addition to xenotime and quartz $[9,10]$; the $\{112\}$ twin lamellae indicate that exposed bedrock may have experienced shock pressures up to $\sim 20 \mathrm{GPa}$ [10]. The $1472 \pm 35 \mathrm{Ma}$ age determined from a shock-twinned zircon is the first reliable maximum impact age constraint based on analysis of shocked material and extends the window for the Santa Fe impact event into the Mesoproterozoic [11].

References: [1] Fackelman et al. (2008) EPSL, 2017, 290-299, [2] Moser et al. (2011) Can. Jour. Earth Sci., 48, 117-139, [3] Erickson et al. (2013) Am. Min., 98, 59-65, [4] Montalvo et al. (2017) Am. Min., 102, 813-823 [5] Thomson et al. (2014) GSA Bull., 126, 720-730, [6] Erickson et al. (2017) Cont. Min. Pet., 176, 6, [7] Cavosie et al. (2015) Geo., 43, 315-318, [8] Timms et al. (2012) Met. Plan. Sci., 47, 120-141, [9] Cavosie et al. (2016) Geo., 44, 803-806, [10] Montalvo et al. 2018, GSA Bull., in press. 